\title{
Pemberdayaan Remaja Putri Melalui Pelatihan Pembuatan Produk Dari Bahan Satin
}

\author{
FAIZAH KAMILAH $^{1}$; ZULIA KHAIRANI ${ }^{2}$; EFRITA SOVIYANTI ${ }^{3}$ \\ 1,2,3 Universitas Lancang Kuning \\ Jln. Yos Sudarso KM 08 Rumbai Telp. (0761) 52581 \\ E-mail : faizahkamilah@unilak.ac.id
}

\begin{abstract}
This Community Service activity aims to provide training in making flowers using satin material that is ready for sale that can foster entrepreneurial spirit and to find out the responses of young women to training in making flower creations using satin material while at the same time fostering an entrepreneurial spirit. The method of community service activities uses the lecture method, demonstrations directly practiced by participants, and question and answer. The lecture method is used to convey general knowledge about the creation of flowers from satin material, the use of satin material, various kinds of flowers made of satin. Demonstrations are used to provide direct skills regarding the process of making satin-based product creations, equipment needed and materials used in making satin products. Question and answer is used to supplement things that have not been accommodated by the method above. This training involved lecturers of Accounting and Management who worked with young women in the village of Tuah Madani Subdistrict, Tampan, Pekanbaru, as the target subject.
\end{abstract}

Keywords: Satin Products, Satin Flowers, Entrepreneurial Training, Young Women

Dengan minimnya pengetahuan tiap kelompok tentang pemasaran produk yang dihasilkan dan masih rendahnya kreativitas anggota dalam membuat kreasi pembuatan produk kerajinan dari bahan satin dan berfikir sangat sulit untuk memasarkan produk yang mereka hasilkan dari kegiatan kelompok ini. Dengan pengajian dan arisan membuat kreasi fungsional tidak perlu memikirkan masalah pemasaran produk (Supardi: 2009:45).

Meskipun tidak tahu sama sekali tentang bagaimana cara memulai sebuah bisnis, namun kesempatan untuk berwirausaha selalu terbuka lebar, dengan cara mengambil sebuah usaha kecil bisa menjadikan solusi tepat untuk membiasakan diri dengan menghasilkan uang secara mandiri tanpa harus selalu bergantung dengan lapangan pekerjaan yang didirikan orang lain. Berwirausaha sendiri bisa menjadikan seseorang lebih tangguh dalam menghadapi tantangan hidup.

Dari hasil pengamatan Tim PKM, banyak remaja putri di Kelurahan Tuah
Madani RT 03 RW 07 yang berjumlah lebih kurang 20 mahasiswi bila hadir semua, sebagian besar mahasiswi pada Universitas Islam Negeri Sultan Syarief Kasim Riau, yang sebagian besar penghasilan mereka hanya mengharapkan kiriman dari orang tua mereka saja setiap waktunya. Maka untuk itu tim PKM memberikan sedikit ketrampilan dalam memanfaatkan bahan dari pita satin ditambah dengan pernik-pernik yang nantinya akan menjadi berbagai produk yang siap untuk dijual. Apabila ketrampilan ini ditekuni bisa menambah penghasilan untuk membantu keuangan mahasiswi tersebut.

Pemberdayaan perempuan sedini mungkin agar menjadi insan yang mandiri yang dapat membantu kesejahteraan keluarga menjadi dambaan setiap wanita Indonesia, sehingga kedudukan wanita sama dengan pria, bersama-sama membangun keluarga dan bangsa Indonesia. Dari hasil observasi dan wawancara dengan remaja putri Keluarahan Tuah Madani diperoleh 
beberapa fakta berkaitan dengan pemberdayaan perempuan dalam kegiatan pengabdian masyarakat ini sebagai berikut:

a. Sangat jarang diadakan pertemuan yang membahas tentang peningkatan kreatiftas perempuan dalam berwirausaha.

b. Perlunya meningkatkan kesejahteraan hidup keluarga melalui peningkatan kreatifitas perempuan dalam berwirausaha.

c. Belum pernah disosialisasikan dan mengikuti pelatihan ketrampilan tentang pembuatan berbagai produk dari bahan satin, yang dapat dijadikan sarana guna meningkatkan kreatifitas.

Atas dasar fakta-fakta hasil observasi maka dipandang perlu Tim pengabdian melakukan pendampingan remaja putri RT 03 RW 07 Kelurahan Tuah Madani Kecamatan Tampan dalam beberapa kegiatan antara lain:

a. Pendampingan masyarakat dalam menyelesaikan masalah remaja putri dengan berinovasi berupa berbagai produk dari bahan satin, sehingga dapat membantu keuangan remaja putri dalam menunjang kesejahteraan hidup.

b. Perencanaan, perancangan dan pembuatan berbagai produk dari bahan satin. Sehingga remaja putri akan memahami pentingnya berwirausaha, berkreatifitas dan inovasi.

c. Pelatihan pelaksanaan pembuatan produk inovasi. Paket pelatihan ketrampilan ini diharapkan mampu menjadi sarana transfer ilmu pengetahuan.

d. Sosialisasi strategi pemasaran diperlukan untuk evaluasi kegiatan agar memperoleh peningkatan pendapatan bagi masyarakat khususnya remaja putri.

Adapun program pelatihan yang akan diberikan adalah membuat kreasi berbagai produk dari bahan satin. Dipilihnya bahan satin sebagai bahan utama pembuatan produk kerajinan karena bahan satin mudah didapat dan harganya tidak terlalu mahal, sedangkan kreasi fungsional yang akan dibuat adalah berupa benda-benda berupa souvenir dan bunga yang memiliki fungsi bagi kehidupan sehari-hari. Kreasi benda fungsional yang akan dibuat adalah souvenir dan bunga.

Kondisi usaha yang dialami remaja putri RT 03 RW 07 Kelurahan Tuah Madani Kecamatan Tampan memerlukan sentuhan dari pihak lain agar terjadi pengembangan usaha yang signifikan. Program pengabdian bagi masyarakat yang telah diselenggarakan berdasarkan latar belakang di atas serta fokus permasalahan yang akan diprioritaskan untuk dipecahkan dalam kegiatan pengabdian masyarakat tersebut. Berdasarkan latar belakang tersebut, program pengabdian masyarakat ini dinamakan "Pemberdayaan Remaja Putri RT 03 RW 07 Kelurahan Tuah Madani Kecamatan Tampan Melalui Pelatihan Pembuatan produk dari bahan satin"

\section{METODE}

Metode yang akan dilakukan oleh tim selama kegiatan pengabdian bagi masyarakat dengan Mitra Kelompok Usaha Remaja Putri RT 03 RW 07 Kelurahan Tuah Madani Kecamatan Tampan yaitu : Enterpreneurship

Motivation, Pendampingan Penyusunan Rencana Bisnis dan Pelatihan dan Workshop Teknik-teknik Produksi baik untuk Kepentingan Pendanaan maupun Pemasaran.

Adapun rencana kerja yang akan dilakukan dalam program ini adalah:

1. Menghubungi Ketua RT 03 RW 07 Kelurahan Tuah Madani Kecamatan Tampan

2. Menghubungi kelompok usaha ibu rumah tangga yang ada dalam kegiatan ini

3. Memberikan pelatihan untuk meningkatkan ketrampilan bagi mitra . 

adalah:

Prosedur kerja yang akan dilakukan

1. Memberikan motivasi bagi semua peserta agar mau mengembangkan usaha kreasi bunga satin menjadi wirausaha yang dapat diandalkan.

2. Memberikan pelatihan bagaimana cara membuat kreasi bunga satin.

3. Memberikan penyuluhan dan pelatihan tentang prospek usaha kreasi bunga satin dan cara membuat analisis usaha.

4. Memberikan penyuluhan bagaimana strategi pemasaran untuk produk yang dihasilkan.

Analisis dilakukan secara deskriptif dengan mendeskripsikan hasil lapangan dan dianalisa Suroto, dkk (2017).

\section{HASIL}

Pelaksanaan kegiatan pengabdian kepada masyarakat ini dilakukan di Kelurahan Tuah Madani Kecamatan Tampan Kota Pekanbaru Riau dengan mitranya kelompok remaja putri. Kegiatan pengabdian ini dilaksanakan pada bulan September s/d Januari 2019. Para peserta yang hadir pada waktu pelaksanaan kegiatan ini adalah kelompok remaja putri di Kelurahan Tuah Madani Kecamatan Tampan Kota Pekanbaru Riau

Adapun peserta remaja putri yang dimaksud kebanyakan dari mereka adalah mahasiswi Universitas Islan Negeri Sultan Syarief Kasim Riau. Dari peserta yang kita harapkan sekitar 10 orang dari Kelompok remaja putri, dan dari harapan tersebut ternyata pesertanya diluar prediksi, jumlah peserta yang hadir berjumlah 15 orang. Disebabkan karena pada waktu melakukan kegiatan pengabdian kepada masyarakat, kelompok remaja putri di Kelurahan Tuah Madani Kecamatan Tampan Kota Pekanbaru Riau yang kebanyakan dari mereka adalah mahasiswi Universitas Islan Negeri Sultan Syarief Kasim Riau sedang libur akhir semester, akan tetapi antusias remaja putri dalam kegiatan pengabdian ini sangat luar biasa untuk bisa berlatih dalam pembuatan produk bunga dari bahan satin. Yang mana nantinya akan bisa dimanfaatkan oleh remaja putri tersebut untuk menambah penghasilan mereka.

Dari hasil ceramah, diskusi, tanya jawab, kami dapat menyimpulkan bahwa peserta sebagian besar sudah memahami tentang berwirausaha tetapi belum begitu menguasai tentang pemasaran yang baik, hal ini dapat dilihat dari hasil quisioner sebelum dan seudah mendapat pembekalan dan materi tentang bagaimana berwirausaha dan pemasaran produk tersebut. Pada akhir sesi dari pengabdian masyarakat ini, para peserta mulai memahami bagaimana cara pemasaran yang baik. Yang perlu kami tekankan disini, bahwa dengan kemampuan skill dan keinginan yang kuat dari kedua mitra pengabdian, kita dapat menyakinkan bahwa meskipun sebagian dari mereka adalah seorang mahasiswi, dengan adanya waktu luang dan kemauan untuk maju dan bisa membantu ekonomi mereka masingmasing, mitra pengabdian dapat berkreasi dari pengabdian yang telah dilakukan.

\section{PEMBAHASAN}

Dalam kegiatan pengabdian masyarakat ini dengan cara menyebarkan quisioner sebelum dan sesudah pelaksanaan pelaksanaan pengabdian. Adapun untuk mengetahui pengetahuan dan pemahaman tentang kewirausahaan dan pemasaran produk, dapat dilihat dari pertanyaan yang telah dijawab sebagai berikut :

Tabel 1 Tanggapan responden tentang pernah tidaknya mengikuti PelatihanKewirausahan dan pemasaran Produk hasil Olahan

\begin{tabular}{|c|c|c|}
\hline $\begin{array}{l}\text { Alternatif } \\
\text { Jawaban }\end{array}$ & \begin{tabular}{|lr} 
Jawaban responden \\
Sebelum mendapatkan \\
Pembekalan \\
Mandiri
\end{tabular} & $\begin{array}{l}\text { Jawaban responden } \\
\text { setelah mendapatkan } \\
\text { Pembekalan } \\
\text { mandiri }\end{array}$ \\
\hline a. Ya & $40 \%$ & $100 \%$ \\
\hline b. Tidak & $60 \%$ & \\
\hline Jumlah & $100 \%$ & $100 \%$ \\
\hline
\end{tabular}

Sumber Data : Data Olahan

Dari tabel di atas dapat dilihat bahwa jawaban peserta sebelum dilakukan pembekalan dan yang mejawab Ya berdasarkan tabel diatas sebanyak $40 \%$ dan 
yang menjawab belum sebanyak $60 \%$. Sedangkan setelah diadakan penjelasan tentang kewirausahaan dan pemasaran produk $100 \%$ mengerti bagaimana kewirausahaan dan Pemasaran produk tersebut yang akan meningkatkan pendapatan remaja putri yang bersangkutan. Selanjutnya untuk mengetahui para peserta sudah pernah atau belum mendapatkan pengetahuan tentang Pemasaran Produk dapat dilihat pada tabel 2 berikut ini:

Tabel 2 Tanggapan responden tentang pernah tidaknya mendapatkan pengetahuan tentang Pemasaran Produk

\begin{tabular}{|l|l|l|}
\hline \multirow{2}{*}{$\begin{array}{l}\text { Alternatif } \\
\text { Jawaban }\end{array}$} & $\begin{array}{l}\text { Sawaban responden } \\
\text { Sebelum } \\
\text { Pembekalan usahaban responden } \\
\text { Mandiri }\end{array}$ & $\begin{array}{l}\text { lawa } \\
\text { setelah mendapatkan } \\
\text { Pembekalan usaha } \\
\text { mandiri }\end{array}$ \\
\hline $\begin{array}{l}\text { c. Ya } \\
\text { d. Tidak }\end{array}$ & $100 \%$ & $100 \%$ \\
\hline Jumlah & $100 \%$ & $100 \%$ \\
\hline
\end{tabular}

Sumber : Data Olahan

Dari tabel diatas dapat diketahui jawaban responden sebelum mendapatkan pembekalan pada kegiatan Kewirausahan Dan Pemasaran Produk Hasil Olahan remaja putri di Kelurahan Tuah Madani Kecamatan Tampan Kota Pekanbaru Riau bahwa responden yang menjawab belum yaitu semua peserta. Dengan demikian sebagian besar peserta belum pernah mendapatkan pemahaman tentang Pemasaran produk, dan sebagian peserta mengatakan bahwa pemahaman tentang Pemasaran produk tersebut ini baru mereka dapatkan. Selanjutnya untuk mengetahui pemahaman tentang puas atau tidaknya produk yang dihasilkan dapat dilihat pada tabel 4 berikut ini.

Tabel 3 Tanggapan responden tentang puas atau tidaknya produk yang dihasilkan

\begin{tabular}{|l|l|l|}
\hline $\begin{array}{l}\text { Alternatif } \\
\text { Jawaban }\end{array}$ & $\begin{array}{l}\text { Jawaban responden } \\
\text { sebelum } \\
\text { Pembekalan usaha } \\
\text { Mandiri }\end{array}$ & $\begin{array}{l}\text { Jawaban responden } \\
\text { setelah mendapatkan } \\
\text { Pembekalan usaha } \\
\text { mandiri }\end{array}$ \\
\hline $\begin{array}{l}\text { a.Ya } \\
\text { b.Tidak }\end{array}$ & $100 \%$ & $100 \%$ \\
\hline Jumlah & $100 \%$ & $100 \%$ \\
\hline
\end{tabular}

Sumber : Data Olahan
Dilihat dari tabel di atas dapat diketahui bahwa jawaban responden sebelum diadakan pembekalan pemahaman tentang puas atau tidaknya terhadap produk yang dihasilkan, banyak yang menjawab tidak dan belum memahaminya, akan tetapi setelah kita berikan materi seluruh peserta hampir memahaminya. Karena hasil olahan tersebut harus berkualitas yang baik sehingga nantinya akan mudah dipasarkan.

Sebelum dimulainya penyampaian materi dan pemberian pembekalan tentang kewirausahaan dan pemasaran produk , kami Tim Pengabdian Masyarakat memberikan kuisioner terlebih dahulu untuk mengetahui sampai sejauh mana para peserta memahami dan mengerti tentang berwirausaha dan pemasaran produk. Setelah dievaluasi ternyata separuh peserta pengabdian tersebut belum memahami bagaimana berwirausaha dan pemasaran Produk. Kemudian pada tanggal 12 Januari 2019 kami melanjutkan untuk memberikan materi dan pembekalan bagaimana Pemasaran Produk dan berwirausaha dengan kemampuan skill yang dimiliki oleh peserta.

Dilihat dari pantauan kami, memang Pelatihan dan tanya jawab yang kami berikan berpengaruh terhadap penerimaan materi yang kami berikan, untuk kelompok remaja putri kegiatan Kewirausahan Dan Pemasaran Produk Hasil Olahan pada Kelurahan Tuah Madani Kecamatan Tampan Kota Pekanbaru Riau, cepat memahami apa yang disampaikan oleh Tim Kami. Dalam melaksanakan kegiatan Pemasaran Produk dan Kewirausahaan dari mitra pengabdian cepat memahami bagaimana cara untuk meningkatkan pendapatan dari usaha yang mereka tekuni. Pada Dasarnya para peserta antusias dalam menerima materi-materi yang diberikan oleh Tim Pengabdian Masyarakat, kita juga maklum dengan keterbatasan kemampuan nalar yang belum terarah untuk memulai usaha sampingan yang akan mendatangkan keuntungan atau meningkatkan pendapatan. Maka dalam memberikan pelatihan Kewirausahan Dan Pemasaran Produk 
Hasil Olahan kelompok remaja putri pada Kelurahan Tuah Madani Kecamatan Tampan Kota Pekanbaru Riau, materi dan bahan pembekalan kita harus mengulangmengulang sampai mereka dapat memahaminya dengan bahasa yang sangat sederhana.

\section{SIMPULAN}

Berdasarkan uraian di atas, dapat disimpulkan bahwa pada tahap awalnya sebelum pemberian pembekalan tentang kewirausahaan dan pemasaran produk pengabdian masyarakat ini diikuti sekitar 25 peserta, yang terdiri 15 dari Kelompok ibu rumah tangga Sri Meranti dan kelompok ibu rumah tangga Rumbai Meranti sebanyak 10 orang, yang diikuti oleh seluruhnya yaitu 25 peserta, Para peserta sebelum diadakan pembekalan tentang kewirausahaan dan Pemasaran Produk, banyak yang belum memahami arti pentingnya keahlian yang dimiliki untuk dapat membuka peluang agar dapat usaha mandiri. Dan setelah dilakukan pembekalan tentang kewirausahaan dan pemasaran Produk, mereka mulai memahami meskipun sulit untuk dapat menerapkannya, karena pemikiran para ibu-ibu dari kelompok mitra tersebut bahwa berwirausaha dan memasarkan Produk membutuhkan modal yang besar. Sedangkan menurut mereka hanya kemampuan keahlian yang mereka miliki.

Sebagai Tim menyarankan kepada para peserta agar mereka lebih menggali keahlian yang dia miliki, termasuk memanfaatkan peluang peluang usaha yang ada, terutama berkenaan dengan keahlian yang dia miliki dibidang pembuatan hasil industri rumahan (pembuatan souvenir dari bahan satin/ handmade). Begitu juga dengan keahlian yang ada, mereka dapat mengembangkan hasil olahan dengan mengikuti kesukaan atau kegemaran dari para masyarakat. Dengan bertambahnya pengetahuan tentang bagaiamana memanfaatkan peluang peluang usaha pengolahan hasil industri kelompok remaja putri dari mitra pengabdian harus berani dalam mengambil keputusan untuk dapat memanfaatkan peluang. Serta sebaiknya untuk membuka usaha mandiri peserta mengusulkan atau mengajukan pinjaman usaha kecil ke Perbankan, atau kedinas UMKM Kota Pekanbaru dan Provinsi.

\section{DAFTAR RUJUKAN}

Buchari Alma, Kewirausahaan, Alfabeta, Bandung, 2010

Suroto, B., Novita, N., Pailis, E. A., Waldelmi, I., \& Fatkhurahman, F. (2017). Metode Penelitian Tindakan Solusi Bagi Masalah Sosial. Jurnal Diklat Review, 1(1), 25-28.

Elni Sumiarti, 2008. Wirausaha Ibu Rumah Tangga untuk Mengatasi Kemiskinan, Jurnal Ekonomi dan Bisnis, Oktober Volume 3, Nomor 2, hal 182.

Reynald, 2010, "Modul Kewirausahaan untuk Program Strata 1", Bank Mandiri dan Yayasan Rumah Perubahan. Jakarta.

Suryana, 2006. Kewirausahaan Pedoman Praktis: Kiat, dan Proses Menuju Sukses. Jakarta. Penerbit Salemba.

Supardi, 2009, Tantangan dan Peluang Bisnis Usaha Kecil dan Menengah, UII Press.Yogyakarta.

Sugiarto, 2011, Undang-Undang dan Peraturan Tentang Usaha Kecil dan Menengah,PenerbitVisiMedia,Jaka rta. 